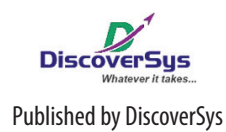

Published by DiscoverSys

\section{Stigma and discrimination: Barrier for ending AIDS by 2030 and achieving the $90-90-90$ targets by 2020}

\author{
Dewa Nyoman Wirawan ${ }^{1 *}$
}

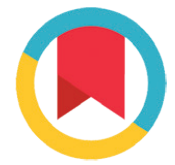

CrossMark
${ }^{1}$ Department of Public Health and Preventive Medicine, Faculty of Medicine, Udayana University

*Correspondence to: Dewa Nyoman Wirawan, Department of Public Health and Preventive Medicine, Faculty of Medicine, Udayana University wirawandewa48@gmail.com
The Joint United Nations Programme on HIV-AIDS (UNAIDS) put forward an ambitious vision of "three zero" which consisted of zero new HIV infections, zero discrimination and zero AIDSrelated deaths. ${ }^{1}$ In other words, it is envisaged there will be no new HIV infections, no more discrimination towards people living with HIV and no more AIDS-related deaths. UNAIDS also set the target of "ending AIDS" as a public health threat by $2030 .{ }^{1}$ In order to end the HIV epidemic by 2030, in 2014 UNAIDS established a fast tract strategy namely "90-90-90" which means by 2020, 90\% of all people living with HIV will know their HIV status, 90\% of all people with diagnosed HIV infection will receive sustained access to antiretroviral therapy (ART) and $90 \%$ of all people receiving antiretroviral therapy will achieve viral suppression. ${ }^{2}$ If this target of "90-90-90" is achieved, it is estimated that by 2020 at least $73 \%$ of all people living with HIV worldwide will experience viral suppression; further modeling suggests that if this target is achieved this will bring about the "end of AIDS" by $2030 .^{2}$

Several studies have shown that the sustained use of ARVs decreases the mortality rate of AIDSrelated illness. ${ }^{3,4}$ UNAIDS reported that through increasing use of antiretroviral drugs, the annual mortality due to AIDS-related illness has declined from a peak of 1.9 million (1.4-2.7 million) in 2004, to $940,000(670,000-1,300,000)$ in 2017 and AIDSrelated mortality has declined by $34 \%$ compared to $2010 .^{5}$

Several other studies have shown that the use of antiretrovirals can inhibit HIV transmission, therefore new HIV infections can be reduced. ${ }^{6-8}$ When people with HIV effectively adhere to ARVs, the HIV concentration in their bodies becomes undetectable and transmission to others is prevented. Thus, the use of antiretroviral drugs has a dual effect, namely reducing mortality and HIV transmission (new infection). In other words, ARVs serve as a treatment and also as a prevention mechanism (treatment as prevention).

Reported achievements regarding the 90-90-90 target vary widely between regions and between countries. In 2017, UNAIDS reported that the Eastern and Southern Africa regions had reached 76\%-79\%-83\%, Western and Central Africa reached 42\%-83\%-73\%, Asia and the Pacific
71\%-66\%-83\%, Latin America 81\%-72\%-79\%, Caribbean 64\%-81\%-67\%, Middle East and North Africa 58\%-41\%-66\%, Eastern Europe and Central Asia 63\%-45\%-77\%. ${ }^{9}$ Countries incorporated in the European Union (European Economic Area) have reported to have reached $86 \%-91 \%-92 \% .^{10}$

Achievements between countries also vary greatly, for example in the Asia and the Pacific Region, target achievements are reportedly quite high in Australia (>89\%->89\%-79\%), Cambodia (82\%->89\%->89\%), Thailand (>89\%-75\%-79\%) and Vietnam (70\%-67\%-73\%). While in several other countries it is still very low such as in Indonesia (35\%-36\%-NA), Bangladesh (33\%-46\%NA) and Afghanistan (29\%-26\%-86\%). ${ }^{9}$

In the Indonesian context, epidemics are concentrated in key populations namely female sex workers, men who have sex with men (MSM), people who inject drugs and clients of female sex workers. The number of female sex workers in Indonesia in 2016 was estimated to be 226,791 (95\%CI: 128,114-364,313), men who had sex with men as many as 754,310 (95\%CI: 648,641-866,840), transgender women numbered at 38,928 (95\%CI: 13,038-89,640 ), 33,492 people who inject drugs (95\%CI: 14,016-88,812), and clients of female sex workers estimated at 5,254,065 (95\%CI: 4,415,776$6,159,431) \cdot{ }^{11}$ In 2015 HIV prevalence among female sex workers in several cities in Indonesia reportedly varied between 2.0-15.0\%, among MSM between $13.2-36.0 \%$, transgender women between 10.2$34.0 \%$ and people who inject drugs estimated at between $4.8-43.6 \% .^{12}$

Some studies showed that the high prevalence of HIV among sex workers and men who have sex with men is compounded by stigma, discrimination and criminalization, which hampers their access to HIV testing services and ART services. ${ }^{13-15}$ Analysis conducted by a team of health experts showed that the decriminalization of sex work would reduce new HIV infections by $33-46 \%$ over the coming decade. $^{13}$

Public campaigning for the ongoing discrimination and criminalization of sex workers and MSM remains high in Indonesia both at the local and national level. ${ }^{16}$ This undeniably impacts negatively upon achieving "90-90-90" in Indonesia, which sits at only 35\%-36\%-NA. ' The results of a cohort 
study on female sex worker and MSM communities in three cities in Indonesia indicated that from 100 individuals who were enrolled as many as $85 \%$ were linked to care, $73 \%$ had initiated ARV treatment, only $55 \%$ had a visit history of at least 2 times within 3 months after ARV initiation and only $35 \%$ presented with a suppressed viral load after 6 months of beginning treatment. ${ }^{17}$ Low levels of ARV retain and unsuppressed viral load were caused by low adherence. Many studies have shown that adherence is indisputably linked to stigma at the intrapersonal, interpersonal and structural level. ${ }^{18,19}$

In order to be able to mirror the achievements of other countries towards 90-90-90, addressing stigma and discrimination towards key populations and people with HIV+ is crucial. Without these efforts ending the AIDS epidemic by 2030 will be challenging to realize and remain a lofty aspiration.

\section{REFERENCES}

1. UNAIDS. The AIDS epidemic can be ended by 2030 . Geneva, Switzerland. 2016.

2. UNAIDS. 90-90-90 An ambitious treatment target to help end the AIDS epidemic. Joint United Nations Programme on AIDS. Geneva, Switzerland. 2014.

3. Andrade HB, Shinotsuka CR, da Silva IRF, Donini CS, Yeh Li $\mathrm{H}$, de Carvalho FB, et al. Highly active antiretroviral therapy for critically ill HIV patients: a systematic review and meta-analysis. PLoS ONE. 2017; 12(10): e0186968. https://doi.org/10.1371/journal.pone. 0186968

4. Montaner JSG, Lima VD, Harrigan PR, Lourenc L, Yip B, Nosyk B, et al. Expansion of HAART coverage is associated with sustained decreases in HIV/AIDS morbidity, mortality and HIV transmission: the "HIV treatment as prevention" experience in a Canadian setting. PLoS ONE. 2014; 9(2): e87872.

5. UNAIDS. Data 2018, Joint United Nations Programme on AIDS. Geneva, Switzerland. 2018.

6. Tanser F, Bärnighausen T, Grapsa E, Zaidi J, Newell ML. High coverage of ART associated with decline in risk of HIV acquisition in KwaZulu-Natal, South Africa. Science. 2013; 339:966-971.

7. Rodger A, Cambiano V, Bruun T, Vernazza P, Collins S, Degen O, et al. Risk of HIV transmission through condomless sex in serodifferent gay couples with the HIVpositive partner taking suppressive antiretroviral therapy (PARTNER): final results of a multicentre, prospective, observational study. Lancet. 2019; 393(10189): 2428-38.

8. Cohen MS, Ying QC, McCauley M, Gamble T, Hosseinipour MC, Kumarasamy N, et al. Antiretroviral therapy for the prevention of HIV-1 transmission. New England Journal of Medicine. 2016; 375(9): 830-839. DOI:10.1056/NEJMoa1600693.
9. UNAIDS. Data 2017, Joint United Nations Programme on AIDS. Geneva, Switzerland. 2017.

10. Brown Alison E, Hayes Rosalie, Noori Teymur, Azad Yusef, Amato-Gauci Andrew J., Pharris Anastasia, et al. The ECDC Dublin declaration monitoring network. HIV in Europe and Central Asia: progress in 2018 towards meeting the UNAIDS 90-90-90 targets. Euro Surveill. 2018; 23(48):pii=1800622. DOI:10.2807/1560-7917. ES.2018.23.48.1800622

11. Ministry of Health of Indonesia, Directorate General Diseases Prevention and Control. Estimasi jumlah populasi kunci HIV di Indonesia tahun 2016 [Estimation of HIV key population in Indonesia 2016]. Jakarta, 2017.

12. Ministry of Health of Indonesia, Directorate General Diseases Prevention and Control. Kajian epidemiologi HIV di Indonesia tahun 2016 [Report on epidemiology of HIV in Indonesia 2016]. Jakarta, 2017.

13. Shannon K, Strathdee SA, Goldenberg SM, Duff P, Mwangi P, Rusakova, M, et al., Global epidemiology of HIV among female sex workers: influence of structural determinants. Lancet. 2015; 385(9962): 55-71. DOI:10.1016/ S0140-6736(14)60931-4.

14. Baral S, Beyrer C, Muessig K, Poteat T, Wirtz AL, Decker $\mathrm{MR}$, et al. Burden of HIV among female sex workers in low-income and middle-income countries: a systematic review and meta-analysis. Lancet Infect Dis. 2012; 12: 53849. DOI:10.1016/S1473-3099(12)70066-X

15. Lazuardi E, Newman CE, Tasya IA, Rowe E, Wirawan DN, Wisaksana R, et al. Understanding the social influences on engaging key populations with HIV prevention: a qualitative study with men who have sex with men in three Indonesian cities. AIDS Education and Prevention. 2019; 31(3): 206-223.

16. United Nations Country Team Indonesia. Report for the universal periodic review of Indonesia, 27th Session, April-May 2017. Available at: https://uprdoc.ohchr.org/ uprweb/ downloadfile.aspx?filename=3939\&file

17. Januraga P, Reekie J, Mulyani T, Lestari BW, Iskandar S, Wisaksana R, et al. The cascade of HIV care among key populations in Indonesia. Lancet HIV. 2018; Published Online August 21, 2018 http://dx.doi.org/10.1016/ S2352-3018(18)30148-6

18. Katz IT, Ryu AE, Onuegbu AG, Psaros C, Weiser SD, Bangsberg DR, et al. Impact of HIV-related stigma on treatment adherence: systematic review and meta-synthesis. Journal of the International AIDS Society. 2013; 16(Suppl 2):18640. DOI: 10.7448/IAS.16.3.18640

19. Corless IB, Hoyt AJ, aawwTyer-Viola L, Sefcik E, Kemppainen J, Holzemer WL, et al. 90-90-90-Plus: Maintaining adherence to antiretroviral therapies. AIDS Patient Care and STDs. 2017; 31(5): 227-236. DOI: 10.1089/apc.2017.0009

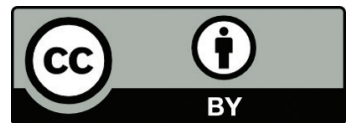

This work is licensed under a Creative Commons Attribution 